\title{
The Job Satisfaction of Non-Civil Servant Nurses in Indonesia Public Hospitals
}

\author{
Tri Siwi Agustina ${ }^{1}$, Yuli Ismiati², Sutinah ${ }^{3}$ \\ ${ }^{1}$ Correspondence Author: siwi@feb.unair.ac.id \\ ${ }^{1}$ Faculty of Ecomonic and Business, Airlangga University, Surabaya, Indonesia \\ ${ }^{2}$ School of Pascasarjana-Airlangga University, Surabaya, Indonesia
}

${ }^{3}$ Faculty of Social and Politics-Airlangga University, Surabaya, Indonesia

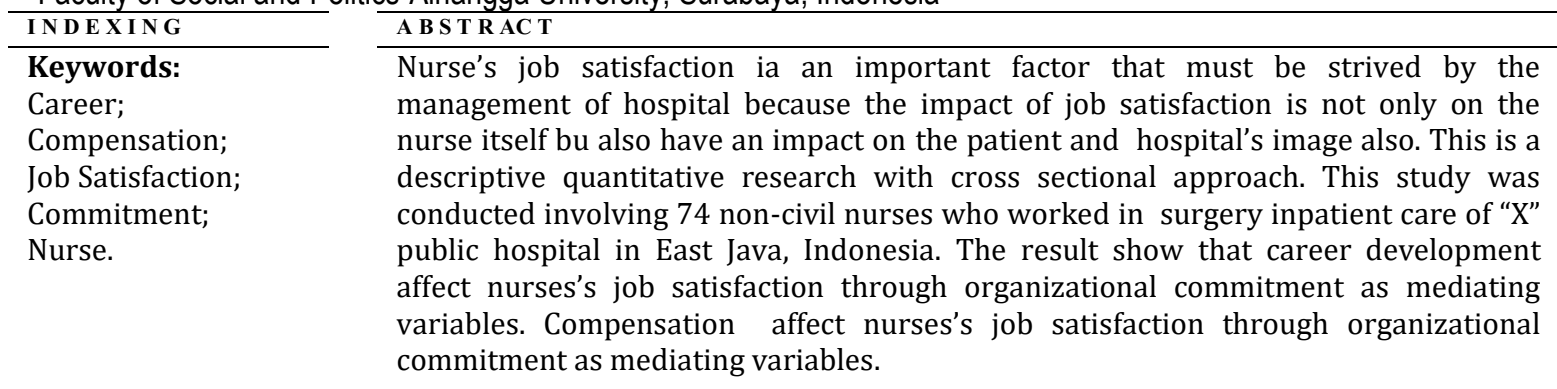

$\begin{array}{ll}\text { Kata kunci: } & \text { Kepuasan kerja perawat merupakan hal penting yang harus diupayakan oleh rumah } \\ \text { Karir; } & \text { sakit karena dampak dari kepuasan kerja tidak hanya pada perawat itu sendiri, namun } \\ \text { Kompensasi; } & \text { juga akan berdampak pada pasien serta citra rumah sakit Penelitian ini menggunakan } \\ \text { Kepuasan Kerja; } & \text { pendekatan desktiprif kuantitatif. Penelitian ini dilakukan terhadap 74 orang perawat } \\ \text { Komitmen; } & \text { yang bekerja pada Instalasi Rawat Inap Bedah di RSUD "X" di Jawa Timur. Hasil } \\ \text { Perawat. } & \text { penelitian menunjukkan bahwa pengembangan karir berpengaruh terhadap kepuasan } \\ & \text { kerja melalui komitmen organisasional sebagai variabel mediasi dan Kompensasi } \\ & \text { berpengaruh terhadap kepuasan kerja melalui komitmen organisasional sebagai } \\ & \text { mediasi. }\end{array}$

Article history: Received 2020-11-22; Revised 2020-12-22; Accepted 2020-12-29

\section{INTRODUCTION}

Instructions for Implementing Nurse Career Paths in the Minister of Health Regulation No. 40 of 2017 states that the professional career path for nurses consists of 4 (four) fields, namely: Clinic Nurse (CN) or in Bahasa namely Perawat Klinis (PK), Manager Nurse (MN or in Bahasa namely Perawat Manager (PM), Educator Nurse (EN) or in Bahasa namely Perawat Pendidik (PP), Research Nurse (RN) or in Bahasa namely Perawat Riset (PR). Each of the 4 fields has 5 levels, namely: Novice or in Bahasa namely Perawat Klinis I (PK-I), Advance Beginner or in Bahasa namely Perawat Klinis 2 (PK-II), Competent or in Bahasa namely Perawat Klinis-III (PK-III), Proficient or in Bahasa namely Perawat Klinis IV (PK-IV) and Expert or in Bahasa namely Perawat Klinis -V (PK-V).

Nurse career development in the form of a nurse career path is a system to explore potentials in accordance with the field of work through increasing competencies that result in professional performance. The career path system will provide opportunities for nurses to develop their competence. The development of professional career path aims to improve work morale and career impasse, to reduce the number of nurses who leave their jobs (turnover), to organize a promotion system based on predetermined requirements and criteria so that career mobility may function properly, to increase the professionalism of 
nurses who are able to provide safe, effective and efficient nursing care, and to increase the satisfaction of individual nurses in their professional fields of work (Indonesia Ministry of Health Regulation, 2017).

Based on this legal basis, the hospital should pay attention to the career development of nurses because neglecting the career development of nurses is equal to neglecting nursing services. Public Hospital "X" in East Java is one of the hospitals in Indonesia that implements PPK-BLUD; they include civil-servant and non-civil servant employees to provide health services for public. The non-civil servant nurses were directly recruited by the hospital because of their needs, and the recruited nurses are compensated by the hospital's budget.

This study was conducted in Public Hospital "X" in East Java with samples that consisted of non-civil servant nurses in the Surgical Inpatient Unit of Public Hospital "X" in East Java. There were 176 nurses in the Surgical Inpatient Unit that included 92 civil-servant nurses and 84 non-civil servant nurses as shown at Table. 1

Table.1Nurses Career Development for Clinical Nurse in the Surgical Inpatient Unit of Public Hospital "X" in East Java Years 2019

\begin{tabular}{cccc}
\hline No & Career Development & Clinical Nurses & Remark \\
\hline 1. & Expert & V & Civil $=0 ;$ Non-Civil $/$ BLUD $=0$ \\
2. & Proficient & IV & Civil $=12 ;$ Non-Civil $/$ BLUD $=0$ \\
3. & Competent & II & Civil $=40 ;$ Non-Civil/BLUD $=3$ \\
4. & Advance Beginner & II & Civil $=30 ;$ Non-Civil/BLUD $=46$ \\
5. & Novice & I & Civil $=10 ;$ Non-Civil/BLUD $=35$ \\
\hline
\end{tabular}

Source: Internal data from Public Hospital "X" in East Java, 2019

The structured career path for non-civil servant clinic nurses $(\mathrm{CN})$ at the Surgical Inpatient Unit of Public Hospital "X" in East Java was still up to level 3 out of 5 levels. In general, at the Public Hospital "X", professional career levels such as Manager Nurses, Educator Nurses, and Research Nurses were currently only intended for civil-servant nurses. The career paths for non-civil servant nurses were at level 3. The disproportionate composition of personnel between level 3 and level 2 in one the Surgical Inpatient Unit and the inability to pursue career paths other than Clinic Nurses $(\mathrm{CN})$ indicate that promotions as part of career development was still an obstacle for non-civil servant nurses at the Surgical Inpatient Unit in Public Hospital "X" in East Java.

Therefore, it is not surprising that in the last 5 years, turnover has quite often occurred at the Surgical Inpatient Unit of Public Hospital "X". Those who resigned were CN1 and CN2 nurses with an age range under 30 years old, and with the most common reason of "resigning because they were accepted on other places". This reason was an indication of a problem with the organizational commitment of non-civil servant nurses at the Surgical Inpatient Unit of Public Hospital "X" in East Java.

The similar studies conducted by Wirani, Arso, Suryawati, (2017) at Prof. DR. Margono Soekarjo Public Hospital Purwokerto, there are differences in the compensation policies received by civil-servant and non-civil servant nurses including the basis of determining salary so that the amount received by civil-servant and non-civil servant nurses was far different. 
Differences in career development and compensation received by civil-servant and noncivil servant nurses certainly have an impact on job satisfaction of nurses in the Surgical Inpatient Unit of Public Hospital "X". Based on the results of a previous study on job satisfaction of 68 non-civil servant nurses who worked at the Surgical Inpatient Unit of Public Hospital "X", it was found that the quality of nurse satisfaction was sufficient. The lowest score was on the elements of workloads, career path, competence and managerial. These results indicated that non-civil servant nurses at the Surgical Inpatient Unit of Public Hospital "X" felt that the 4 elements had not been maximally fulfilled their satisfaction as nurses, as shown at Table.2 below:

Tabel.2 Job Satisfaction Non-Civil Servant Nurses Survey On Desember 2019

\begin{tabular}{|c|c|c|c|}
\hline No & $\begin{array}{l}\text { Job Satisfaction Factors } \\
\end{array}$ & IKK & Category \\
\hline 1 & Competencies* $^{*}$ & 61.21 & $\mathrm{C}$ \\
\hline 2 & Work Environment & 61.69 & $\mathrm{C}$ \\
\hline 3 & Remuneration & 61.77 & $\mathrm{C}$ \\
\hline 4 & Job Interaction & 75.01 & $\mathrm{~B}$ \\
\hline 5 & Workload*) & 48.08 & $\mathrm{D}$ \\
\hline 6 & Career Development*) & 60.34 & $\mathrm{C}$ \\
\hline 7 & Communication & 78.41 & $\mathrm{~B}$ \\
\hline 8 & Job Appraisals based on SKP & 65.03 & $\mathrm{C}$ \\
\hline 9 & Management*) & 61.07 & $\mathrm{C}$ \\
\hline 10 & Leadership & 63.90 & $\mathrm{C}$ \\
\hline & Score of IKK (Indeks Kepuasan Karyawan) & 64.25 & $\mathrm{C}$ \\
\hline \multicolumn{2}{|c|}{ Mean of Satisfaction Category } & C (Moderate) & \\
\hline
\end{tabular}

Source: Survey Pre-Research (2019)

As a type A referral hospital, where the number of referred patients is more than the other types', the availability of nurses is also very important to be considered. The imbalance between the number of nurses and the number of patients will result in a workload that has an impact on nurses' job satisfaction. Therefore, an unclear career path of non-civil servant nurses in Public Hospital "X" is a serious matter. Thus, the shortage of nurses due to the turnover that occurs does not interfere with the operation of Public Hospital "X" services. Of course, the high number of nurse turnover phenomenon experienced by Hospital " $\mathrm{X}$ " in 2019 as a result of career uncertainty (Muslim and Sutinah, 2020) was expected not to occur in Public Hospital "X".

Career development and compensations are forms of appreciation for nurses for their competence and performance while working in the hospital. When a nurse's career in a hospital does not develop, it disturbs the nurse's commitment to the organization. When nurses' satisfaction with her job is not maximized, it means that there are serious problems that need to be addressed in the hospital. Nurses who are not satisfied will have an impact on themselves and their patients, of course, this will also have an impact on the quality of hospital services (Asegid, Belachew, \& Yimam, 2020).

This study aims to fill the gaps from previous studies on the topic of the effect of compensation and career development on nurse job satisfaction. A study by Muslim and Sutinah (2020) described the Professional Career Development of Non-civil servant nurses at Hospital "X". The similarity of the study lies in the professional career development of Non- 
civil servant nurses. Whilst, the difference is that the previous study did not analyze the effect of Career Development, Compensation and Organizational Commitment on Job Satisfaction. Furthermore, the object of their study was the Academic Hospital - Type B, while this study is the Public Hospital as well as the Academic Hospital - Type A. Another study involving mediating variables has been conducted by Gunawan (2017) on 72 nurses, which entitled "The effect of compensation and career development on nurse job satisfaction mediated by work motivation at Bina Kasih Hospital Pekanbaru". The study has similarities in the independent variables, namely compensation. Whilst, career development and job satisfaction were the dependent variables. The difference is that the study used work motivation as a mediating variable whereas this study involved organizational commitment as the mediating variable. In addition, the study was conducted in a private hospital, so that the employment status was different from this study that used civil-servant and non-civil servant nurses who worked at a Public Hospital.

Studies on the effect of career development on job satisfaction of nurses in Indonesia had been conducted by Pradiptha, Widaningsih, and Anwar (2018), Gunawan (2017), Pitri, Suparman, and Nurmayanti (2017). Various results were found in the studies conducted by Wirani, Arso, Suryawati, (2017) at Prof. DR. Margono Soekarjo Public Hospital Purwokerto, there was a difference in the effect of advancement or career development opportunities for civil-servant and non-civil servant nurses. The civil-servant nurses stated that the opportunities for advancement that they received resulted in job satisfaction. On the other hand, most non-civil servant nurses felt that the opportunities for advancement in the hospital were still low due to the lack of clarity in career paths, which resulted in job dissatisfaction. Based on these previous studies, the research hypotheses that can be proposed are as follows:

H1: Career Development has an impact on the job satisfaction of non-civil servant nurses at the Surgical Inpatient Unit of Public Hospital "X" in East Java.

Apriliani and Hidayah (2020) conducted a study on the effect of remuneration (compensation) on job satisfaction of nurses at PKU Muhammadiyah Gamping Hospital. The results of this study stated that remuneration had a positive and significant effect on job satisfaction. A study by Wirani V., Arso S.P., Suryawati C., (2017) stated that there is a difference in satisfaction with the compensation received by civil-servant and non-civil servant nurses at Prof. DR. Margono Soekarjo Public Hospital Purwokerto. The civil-servant nurses stated that they received high amount of salary and felt that it was sufficient for daily needs. The allowances they received were deemed sufficient. On the other hand, most of the noncivil servant nurses still received low compensation from the. The allowances received by noncivil servant nurses were deemed not able to meet their daily needs thus it did not lead to job satisfaction. Based on previous studies, the research hypotheses that can be proposed are as follows:

$\mathrm{H} 2$ : Compensation has positive and significant impacts on job satisfaction of non-civil servant nurses at the Surgical Inpatient Unit of Public Hospital "X" in East Java.

Oktariandini's (2015) study entitled "The Effect of Organizational Career Development on Nurse Commitment in Dr. Hasan Sadikin Hospital Bandung" concluded that career development in the form of education, training, performance appraisal as well as transfers and promotion have positive and significant effects on the commitment of the nurses who 
worked there. Based on previous studies, the research hypotheses that can be proposed are as follows:

H3: Career development has impacts on organizational commitment of non-civil servant nurses at the Surgical Inpatient Unit in Public Hospital "X" in East Java.

Fair and proper compensation will bind employees to be involved in the organization and to decide to stay in the organization. Fair and proper compensation also gives a sense of pride to be part of the organization. In line with the opinion of Nawab and Bhatti (2011), it was found that compensation affected the job satisfaction and organizational commitment. A study on the effect of compensation on nurses' organizational commitment in a hospital was conducted by Annur (2017). The results stated that compensation can increase organizational commitment. Based on previous studies, the research hypothesis that can be put forward is as follows:

H4: Compensation has impacts on organizational commitment of non-civil servant nurses at the Surgical Inpatient Unit of Public Hospital "X" in East Java.

Nurses whose career development is satisfactory will feel that the organization has paid attention to their performances and will decide to remain a member of the organization and willing to be involved in it. The relationship between organizational commitment and job satisfaction has broad impacts, where the impact includes the employee's own performance and also organizational performance. Tobing's (2009) research on 174 employees of PTPN III in North Sumatera concluded that affective commitment, continuous commitment, and normative commitment have a significant effect on job satisfaction. In line with this, Luthans (2006) stated that employees with high organizational commitment may increase their job satisfaction, job satisfaction will improve when workers have high organizational commitment, so that they can work well together and comfortable.

In the context of organizational commitment to nurses' job satisfaction, a study conducted by Hsu, Wang and Lin (2015) on 132 nurses in Northern Taiwan resulted in a finding that professional commitment as a nurse affected the job satisfaction. Based on previous studies, the research hypotheses that can be proposed are as follows:

H5: Career development has impacts on job satisfaction with organizational commitment as the mediating variable of the non-civil servant nurses at the Surgical Inpatient Unit in Public Hospital "X" in East Java.

As workers who provide health services and are vulnerable to health risks, nurses who receive fair and proper compensation will feel satisfied if the organization they work with has provided compensation for their performance. Nurses will also decide to remain a member of the organization and willing to be involved in it. Job satisfaction will be improved when workers have a high organizational commitment in the organization. Thus, workers can focus on working without being burdened by the thoughts about fulfilling the needs. Based on previous studies, the research hypotheses that can be proposed are as follows:

$\mathrm{H} 6$ : Compensation has impacts on job satisfaction with organizational commitment as the mediating variable of the non-civil servant nurses at the Surgical Inpatient Unit in Public Hospital "X" in East Java.

\section{RESEARCH METHOD}

This study used a quantitative approach with an explanative type. The population in this study were 84 non-civil servant nurses from the Surgical Inpatient Unit of Public 
Hospital "X" in East Java, Indonesia. The sampling technique used was a total sampling of 84 nurses by sending a questionnaire via Google Form in the second week to the fourth week of April 2020. In this study, career development was the first independent variable (X1) and was operationally defined as a variety of self-development activities undertaken by non-civil servant nurses who worked in the Surgical Inpatient Unit Public Hospital "X" to realize their personal career plans. The question items in the questionnaire were based on aspects of career path development for nurses developed by Rose and Nunnery (2016) which consisted of job performance, exposure, organizational loyalty, mentors and sponsorship, opportunities for growth and management support.

In this study, compensation was the second independent variable (X2) and was operationally defined as everything that was received by non-civil servant nurses who worked in the Surgical Inpatient Unit Public Hospital "X" as remuneration for their work. The measurement of the compensation variable received by nurses was based on the direct compensation and indirect compensation. In this study, job satisfaction was the dependent variable $(\mathrm{Y})$ and was operationally defined as a way for civil servant nurses from the Surgical Inpatient Unit of Public Hospital "X" in East Java to feel proud about themselves and their job. The question items on the questionnaire were based on nurses' job satisfaction measurement from Siew PL., Chitpakdee B, Chontawan R (2011) with the dimensions of Pay, Autonomy, Task Requirements, Organizational Policies, Interaction and Professional Status.

Organizational commitment in this study was a mediating variable (Z) and was operationally defined as a strong will to be a nurse in Public Hospital "X" in East Java. The measurement of the nurse commitment variable was based on the measurement of organizational commitment by Allen and Meyer (2013) which consists of 3 dimensions, namely affective commitment, normative commitment, and continuance commitment. The gathered responses were categorized into 5 Likert scales ranging from Strongly Disagree (point 1) to Strongly Agree (Point 5). The scores were then added and divided by the number of items to obtain a mean. The data analysis technique used was path analysis to test research hypotheses accompanied by classical assumption tests.

To assess questionnaire validity and reliability, researchers conducted validity and reliability tests. The number of respondents involved in the validity and reliability tests was 74 non-civil servant nurses who worked in the Surgical Inpatient Unit Public Hospital "X using Product Moment Pearson Test and Cronbach's Alpha Test. All of statement items in the questionnaires had scores more than $r$ table $=0.229$, thus it could be concluded that the research instrument was valid. The Cronbach's alpha value was at 0.854 for development career, 0.855 for compensation, 0.908 for job satisfaction, and 0.918 for organizational commitment. In conclusion, the questionnaire was reliable (Cronbach's alpha value >0.06).

The Normality test was conducted using the Kolmogrov-Smirnov test. The first equation conducted was the impact of career path and compensation towards organizational commitment, with Asymp. Sig. (2-tailed) value of $\alpha=5 \%$. In addition, the test determined to accept $\mathrm{HO}$ that concluded that data was distributed normally. The second equation was about the development impact of career path, compensation, and organizational commitment towards job satisfaction, with Asymp. Sig. (2-tailed) value of 0.921. The value was greater than 
$\alpha=5 \%$ and thus determined to accept the $\mathrm{HO}$ that concluded that data was distributed normally.

According to the Multicollinearity test result on the first equation, the VIF of career development and compensation was 1.825 (VIF < 10) thus there was no multicollinearity on the first equation. As well as the second equation, the VIF of career development was 2.338, the VIF of compensation was 2.725, and the VIF of organizational commitment was 3.326 with all of the free variable tolerance was greater than $5 \%$ thus there was no multicollinearity. According to the Heteroscedasticity test result on the first equation, the output obtained significant values of every variable are as follow: a.) Career development variable $=0.513 ; b$.) Compensation variable $=0.216$. Because these significant values are $>\alpha=0.05$, thus it indicates that there was no heteroscedasticity in the data. As well as the Heteroscedasticity test result on the second equation, the output obtained significant values of every variable are as follow: Career development variable $=0.894$; b.) Compensation variable $=0.487$. These significant values are $>\alpha=0.05$, in conclusion there was no heteroscedasticity in the data.

\section{RESULT AND DISCUSSION}

The respondents in this study were non-civil servant nurses who worked in the Surgical Inpatient Unit of Public Hospital "X" in East Java. The total number of nurses with this status was 84 people, while the response rate or questionnaire returned was 74 people or $88.1 \%$ of the original number. A summary of demographic characteristics is as follows :

Females constituted $67.6 \%$ of the respondent group, while $32.4 \%$ were male. The majority $(64.9 \%)$ of the participants were $30-40$ years old, $29.7 \%$ less than 30 years old, and only $5.5 \%$ were older than 40 years of age. Nearly two-thirds of the participants were married. $25.7 \%$ less than 5 years of work experience, half of the respondents had 5-10 years of work experience, while $27.1 \%$ had $11-20$ years of experience. Based on the career development, the percentage of $\mathrm{CN}$ I was $39.2 \%$, CN II was $55.4 \%$, CN III was $5.4 \%$. Based on the education background, the percentage of Diploma 3 /Vocational Graduates was $56.67 \%$, while the others were bachelor graduates of $9.4 \%$ and Master graduates of $7.9 \%$ all according to the manual book of organizing Surgical Inpatient Unit. This matter was accordance with the Ministry of Health Regulation No. 40 of 2017 about nurses' career development.

The results of descriptive testing to obtain the mean value per research variable were as follows: the mean of the career development variable was 4.12 (high category); the mean of the compensation variable was 4.21 (very high category); the mean of the variable organizational commitment was 4.13 (high category); the mean of the job satisfaction variable was 4.20 (high category).

The effect of career development (X1) on job satisfaction (Y) was significant. Path Coefficient of 0.383 , ttest 3,290, Sig. Value $0.002<0.05(5 \%)$ Thus, the first hypothesis of the study which suspected that career development had a positive and significant effect on nurses' job satisfaction from the Surgical Inpatient Unit of Public Hospital "X" was proven. As mentioned in the previous section, the career development of nurses at Public Hospital "X" currently did not have a structured career path in accordance with Ministry of Health Regulation no. 40 of 2017 for non-civil servant nurses as well as nurses with civil-servant status. Nevertheless, when viewed from the working period of non-civil servant nurses in the Surgical Inpatient Unit, the majority were in the range of 5 years to 20 years. The opportunity to gain knowledge and experience while being a nurse in Public Hospital "X" as 
well as the opportunity to take part in training and development such as workshops and seminars, room rotation, promotion to functional positions were perceived to increase their job satisfaction.

Public Hospital "X" in East Java does not only serve medical treatments, but it is also the largest academic hospital, a research house, and a referral hospital in eastern parts of Indonesia. In carrying out its functions, Public Hospital "X" was supported by specialist doctors, professors from the Faculty of Medicine of a state university, health consultants, nurses, and supporting medical staffs who were adept and experienced. Therefore, the longer they interact with these parties in the scope of work, the nurses' experience and knowledge will hone the experience and knowledge and can increase their competence and professionalism in the workplace. This statement is in line with the opinion of Olatunji and Mokuolu (2014) about tenure affects the job satisfaction of nurses and doctors. The longer they work the better. Paramedics who have worked for 5 to 10 years will show higher job satisfaction than those who have worked less than 5 years.

The explanation above is supported by the statement about the results of the mentor and sponsorship dimension from the development of a nurse's career path with the question item. The statement "Doctors and senior nurses do not hesitate to help and provide directions when I encounter difficulties" has a mean of 4.28 which was classified as very high. The dimension of interaction regarding job satisfaction with the question item "I have helpful co-workers to help my work" has a mean value of 4.59 which includes in the very high category. As CN I and CN2 nurses at the highest referral hospital in Eastern Indonesia, there were many variations in tasks and complexity of tasks in handling patients. The assistance and direction of doctors and senior nursing colleagues was very satisfying for them because they allowed them to complete their work well and added meaningful experience to their careers. This condition of mutual assistance in work was very common for nurses in Indonesia because according to Siew PL., Chitpakdee and Chontawan (2011) the culture of Asian society is a culture of collectivism. There is the tendency to help one another whenever needed regardless of status, and prioritizing teamwork over individual. This, of course, cannot be found in western culture that adheres to individualistic values.

The effect of compensation (X2) on job satisfaction (Y) was significant, Path Coefficient of 0.395 , ttest 3,486, Sig. Value $0.001<0.05(5 \%)$ These results have proven the hypothesis of the two studies which suspected that compensation has a positive and significant effect on job satisfaction of non-civil servant nurses from the Surgical Inpatient Unit of Public Hospital "X" in East Java. It is based on the description of the respondents' answer regarding compensation, namely "Appropriate compensation will help me meet the needs of daily life" with a mean value of 4.46 which was classified as very high. Furthermore, the direct and indirect compensation received was in the form of remuneration based on productivity, performance appraisals, provision of annual leave, maternity leave, and medical allowances provided by Public Hospital "X" in East Java. They have been proven to increase job satisfaction for non-civil servant nurses from the Surgical Inpatient Unit of Public Hospital "X" because they were considered to be able to meet their daily needs. Indeed, in a situation of economic crisis and high healthcare costs as what happened in Indonesia, the compensation given by Public Hospital "X" for non-civil servant nurses was felt to be very beneficial. It is due to the fact that the quality of nurses' life was guaranteed by government 
facilities. The results of testing the second hypothesis are in line with the opinion of Suhartini (2009) which stated that compensation is a major element in creating employee job satisfaction, meaning that the more satisfied an employee is with the compensation they receive, the more satisfied the employee will be with his job, and vice versa.

Currently, the remuneration received by non-civil servant nurses in Public Hospital "X" was based on performance appraisals. This is indeed in accordance with the opinion of Azwir, Ayuningtyas and Riastuti (2010) who argued that an improvement in a nurse's career path is always followed by an award (remuneration) either in the form of education support or increasing the income. The increase in nurse's income must be accordance with their achievements and competencies.

The response to the item "Comparing the similar responsibilities and workloads in other hospitals, I consider that my allowance is fair" with a mean value of 4.28 which included a very high category. The non-civil servant nurses compared the remuneration they received from other hospitals which gave the amount of remuneration based on rooms instead of based on work productivity. After comparing, it turned out that the amount of remuneration they received was higher and in accordance with the performance they had carried out. The response can be interpreted that the external justice applied by Public Hospital "X" in East Java has improved job satisfaction. External justice is a position of compensation provided by an organization to an employee compared to compensation provided by the competing companies. If employees feel that the compensation, contents, and the determination method are unfair, they will not experience satisfaction about the compensation (Suhartini, 2009).

Among the very high mean value of compensation, there was an interesting finding on the indirect dimension of compensation with the question item "The organization facilitates me to continue to higher education" which has a mean value of 2.30 which was considered low. This indicated that even when they were satisfied with their job as nurses, they still wished to be able to continue their education to a higher level as the majority their education background was diploma degree instead of bachelor degree. This expectation is indeed very reasonable because it is based on the willingness to improve their performance and professionalism.

The effect of career development (X1) on organizational commitment (Z) was significant, with a large impact of 0.553 . Path Coefficient of 0.553 , ttest 4,468 , Sig. Value $0.000<0.05(5 \%), \mathrm{R}$ square 0.699 . These results has proven that the third hypothesis of research about career development has a positive and significant effect on the organizational commitment of non-civil servant nurses in Public Hospital "X".

For nurses, the opportunities to gain knowledge and experience includes various activity namely interacting with specialist doctors, professional nurses, and supporting medical personnels who are qualified in the scope of public health services in a hospital that is the highest reference in the Eastern Indonesia region. Furthermore, working in an academic hospital as well as a research hospital is valuable experience to increase professionalism as a non-civil servant nurses in Public Hospital "X". Of course, these conditions are rare to be found in other hospitals, so their willingness to always be involved is the basis of their desire to stay in the organization (strong commitment to continuity).

This statement is supported by the career development question item "I feel the need to continue to develop my own potential" which has a mean value of 4.62 which is a very high 
category. The item on the affective commitment dimension with the item question of "I feel the service I provide will help patients to recover" has the highest mean value of 4.15 which is considered high. It means that the non-civil servant nurses from the Surgical Inpatient Unit of Public Hospital "X" had a strong affective commitment. The notion was proven by the willingness to develop their potential as a competent and professional nurse. The dedication was done to fulfill their responsibility to care for the patients.

Allen and Meyer (2013) described Continuous Commitment as an individual commitment based on considerations of what must be sacrificed when they leave the organization. In this case, the individual decided to stay in the organization because they considered their job important for their lives. The response that indicates continuous commitment with the question item of "I will reconsider if there are other organizations that provide a job opportunity for me" has a mean value from the continuous commitment dimension of 2.60 which considered in a low category.

It can be interpreted that non-civil servant nurses from the Surgical Inpatient Unit of Public Hospital "X" had a strong desire to remain in the organization. When the statement was related to the age of the respondents in this study between the ages of 30 to 40 years with a total of $64.9 \%$ with a majority working period of at least 5 years and more than 20 years, they wish to continue their careers as nurses from the Surgical Inpatient Unit of Public Hospital "X" even with the status as non-civil servants. Nonetheless, this age range was not in accordance with the demands of the labor market, which generally requires people under 30 years of age, thus they are less likely to get the opportunity to work in other hospitals. In addition, in terms of marital status, the majority of whom were married indicated that married nurses have a higher financial burden and responsibility on the family than those who were single. Leaving the current organization would certainly disrupt their family life. Therefore, this study complements Oktariandini's (2015) research on the effect of career development on the commitment of nurses in public hospitals in Indonesia.

The effect of compensation (X2) on organizational commitment (Z) is significant, Path Coefficient of 0.660 ttest 5,016, Sig. Value $0.000<0.05(5 \%)$, R square 0.699 , based on these results, the fourth hypothesis of the studies which suspected that compensation has a positive and significant effect on organizational commitment to non-civil servant nurses from the Surgical Inpatient Unit of Public Hospital "X" in East Java was proven.

Based on the high mean value on the compensation variable and the mean value on the question item "I have another job outside the hospital i.e. home care, a nurse in a specialist clinic", it can be interpreted that the compensation received as a non-civil servant nurse from the Surgical Inpatient Unit of Public Hospital "X" did not decrease their organizational commitment by not looking for other sources of income other than what they received from Public Hospital "X" in East Java.

The feeling of satisfaction with the compensation received increased the responsibility of non-civil servant nurse from the Surgical Inpatient Unit of Public Hospital "X" to stay because it was also driven by the feeling that they were obliged to be loyal to their organization. The notion was also indicated that the normative commitment of non-civil servant nurse from the Surgical Inpatient Unit of Public Hospital "X" was strong.

The direct and indirect compensation received in the form of salaries / wages and remuneration based on work appraisals, provision of annual leave, maternity leave, and 
medical allowances provided by Public Hospital "X" in East Java were proven to be able to bind non-civil servant nurse from the Surgical Inpatient Unit not to leave the organization. The response to the question item of "Comparing the similar responsibilities and workloads in other hospitals, I consider that my allowance is fair" got a mean value of 4.28 which was considered as a very high category. When related to organizational commitment, this cannot be separated from the perception of fairness after comparing their responsibilities and workload as nurses in other hospitals that used rooms as the basis for determining remuneration. Whilst, they received remuneration based on performance appraisals in Public Hospital "X". This is in line with the opinion of Oktarini and Indrawati (2014) that employees who have a positive attitude towards compensation will judge that the compensation provided by the organization is fair so that it shows the employee's willingness to remain in the organization and has an attitude of loyalty and accepting values.

The fifth hypothesis which stated that career development affects job satisfaction through organizational commitment to non-civil servant nurses at Public Hospital "X" in East Java was proven because the coefficient path value of the indirect impact was 0.126 with positive impact, thus the fifth hypothesis was accepted. Likewise, the sixth hypothesis which stated that compensation affects job satisfaction through the organizational commitment of non-civil servant nurses Public Hospital "X" was also proven because the coefficient path value of the indirect impact was 0.130 with positive impact, thus sixth hypothesis was accepted.

Job satisfaction for a nurse is very important because it does not only affect the nurse but also the patients and the hospital where the nurse works. Currently, the implementation of career development for non-civil servant nurses in Public Hospital "X" was not in accordance with Ministry of Health Regulation No. 40 of 2017. Thus, the nonexistence of the career path becomes an obstacle for non-civil servant nurses to be able to improve their competence and professionalism. Even so, non-civil servant nurses from the Surgical Inpatient Unit of Public Hospital "X" in East Java had quite satisfied with their career development. This results contradicted the research of Wirani, Arso and Suryawati, (2017) which stated that most of non-civil servant nurses in Prof. DR. Margono Soekarjo Hospital Purwokerto experienced dissatisfaction in their career development.

The non-civil servant nurses of Public Hospital "X" perceived the compensation as fair and proper for it has met their daily needs. They also felt proud about it because the compensation they received had a competitive advantage compared to other hospitals, thus their job satisfaction increased. This result was also different from the research conducted by Wirani, Arso and Suryawati C., (2017) which stated that non-civil servant nurses at Prof. DR. Most of Margono Soekarjo Hospital Purwokerto were dissatisfied with the compensation they received. Nurses may carry out nursing care activities if they were supported by the provision of fair and appropriate compensation in order to create a work commitment and improve increase their job satisfaction.

The results of this study also discovered that the age and years of service had contributed to their perceptions of career development and the compensation. In addition, the career development for non-civil servant nurse from the Surgical Inpatient Unit of Public Hospital "X" in East Java was not in accordance with the government regulations, and the compensation they received was different from fellow nurses who were civil servants. This statement supports the results of study by Eleswed and Mohammed (2013) that health 
workers appear happy and have a higher dedication to their profession than health workers who are still young and had just worked there.

The mediation role of Organizational commitment on the impact of career development and compensation on job satisfaction means that to increase the effect of selfdevelopment and compensation on job satisfaction of non-civil servant nurses of Public Hospital "X", it is absolutely necessary to pay attention to organizational commitment. Luthans (2006) stated that employees with high organizational commitment can improve their job satisfaction, job satisfaction will be better when workers have high organizational commitment in the organization, so that they can work well and comfortably.

Various national and international accreditations had been achieved by Public Hospital "X". In 2018, they won accreditation for General Academic Hospital by the International Joint Commission (JCI). The national accreditation was achieved in 2017 as the Main Academic Hospital of a state university and National KARS Paripurna National Reaccreditation. The national and international recognition achieved by Public Hospital "X" in East Java certainly brought a sense of pride to anyone who worked there because being a part of a reputable organization was also felt by non-civil servant nurse from the Surgical Inpatient Unit of Public Hospital "X".

The willingness to improve their competence and professionalism as a nurse was based on the responsibility of providing quality services to patients, institutions, ethics, laws, and professional standards, and their performance contributes to the assessment of health services and client satisfaction in the organization. (Sirajudin Noor, Nursalam and Tintin Sukartini, 2020).

\section{CONCLUSION}

Non-civil servant nurses in Public Hospital "X" East Java currently do not have a clear structured career path. In addition, there were differences in compensation compared to civil-servant nurses. Even so, the non-civil servant nurses in the hospital had high commitment and high job satisfaction. The Organizational commitment had been shown to mediate the impacts of career development and compensation on job satisfaction. The recommendation for Public Hospital "X" is to internally pay attention to the organizational commitment of non-civil servant nurses with a minimum work period of 5 years. The deeds can be done by focusing more on developing broader career paths such as nurse managers, or research nurses. With this attentive effort regarding the career development, the job satisfaction of non-civil servant nurses shall be maintained.

\section{REFERENCE}

Allen, N. J. and Meyer, J. P. (2013). The Measurement and Antecedents of Affective, Contintinuance and Normative Commitment to Organitazion. Jakarta: PT Elex Media Komputindo.

Apriliani E. and Hidayah N., (2020), Hubungan Remunerasi dan Motivasi Kerja dengan Kepuasan Kerja Perawat di RS PKU Muhammadiyah Gamping, Jurnal Ilmiah Universitas Batanghari Jambi, $20 \quad$ (1) ; https://www.researchgate.net/deref/http\%3A\%2F\%2Fdx.doi.org\%2F10.33087\%2Fjiu bj.v20i1.777 
Annur, M. F. (2017). Pengaruh Kompensasi, Kepuasan Kerja dan Budaya Organisasi pada Komitmen Organisasional Perawat Rumah Sakit PKU Muhammadiyah Temanggung. Publikasi Ilmiah. Fakultas Ekonomi Universitas Negeri Semarang. https://lib.unnes.ac.id/30727/1/7311413234.pdf

Azwir, Ayuningtyas D and RiastutiK., (2010). Pengembangan Pola Karir Perawat Klinik Rumah Sakit Umum Daerah Tarakan Jakarta Pusat Tahun 2008. Jurnal Manajemen Pelayanan Kesehatan, 13(01), 16-22.

Baraba, R. (2013). Pengaruh Lingkungan Kerja Dan Komitmen Organisasi Terhadap Kepuasan Kerja Perawat Pada RSU Muhammadiyah Tunas Medika Purworejo. $\begin{array}{llll}\text { Journal Bisnis: Teori dan } & \text { 61-71. }\end{array}$ https://journal.umy.ac.id/index.php/bti/article/view/2435

Eleswed M and Mohammed F. (2013), Job satisfaction and organizational commitment: a correlational study in Bahrain. Int J Bus Humanit Technol;3(5):44-53, http://ijbhtnet.com/journals/Vol 3 No 5 May 2013/6.pdf

Gunawan, A., (2017), Pengaruh Kompensasi Dan Pengembangan KarirTerhadap Kepuasan Perawat Yang dimediasi Oleh Motivasi Kerja Pada Rumah Sakit Bina Kasih Pekanbaru, JOM Fekon Vol. 4 No. 1 (Februari) 2017, 870 - 883, https://media.neliti.com/media/publications/116530-ID-pengaruh-kompensasi-danpengembangan-kar.pdf,

Hardjanti,I.W, Nanditya IF and Hartojo, (2016), Pengembangan Jenjang Karir sebagai Strategi Mengelola Ketidakpuasan Kerja Perawat di Rumah Sakit, Pengembangan Jenjang Karir sebagai Strategi Mengelola Ketidakpuasan Kerja Perawat di Rumah Sakit | Hardjanti $\mid$ Jurnal Kedokteran Brawijaya (ub.ac.id), Vol 29 (3), pp. 285-290

Hsiu-Chin Hsu, Pao-Yu Wang and Li-Hui Lin, (2015), Exploring the Relationship Between Professional Commitment and Job Satisfaction Among Nurses, https://doi.org/10.1177\%2F2165079915591400

Muslim, A, and Sutinah (2020), Pengembangan Karier Profesional Perawat Non PNS di Rumah Sakit X, Jurnal Manajemen Kesehatan Yayasan RS.Dr.Soetomo, Vol.6, no 1, 16 - 27 , https://jurnal.stikes-yrsds.ac.id/index.php/JMK/article/view/262,

Nawab,S., Bhatti, KK., (2011), Influence of Employee Compensation on Organizational Commitment and Job Satisfaction : A Case Study of Educational Sector Pakistan, International Journal of Business and Social Science, Vol 2 (8), 25,32, www.ijbssnet.com

Oktariandini, NR., (2015). Pengaruh Pengembangan Karir Organisasi Terhadap Komitmen Perawat Pada Rumah Sakit Umum Pusat Dr. Hasan Sadikin Bandung. Publikasi Ilmiah. Fakultas Bisnis dan Manajemen Universitas Widyatama, https://repository.widyatama.ac.id/xmlui/handle/123456789/6346

Oktarini, KRD and Indrawati, KR.,(2014), Hubungan Antara Persepsi Terhadap Keadilan Kompensasi dengan Komitmen Organisasi di Hospitality Industry, Jurnal Psikologi Udayana 2014, Vol. 1, No. 291-300, https://ojs.unud.ac.id/index.php/psikologi/article/download/25089/16302

Olatunji, SO and Mokuolu, BO.,(2014), The Influence of Sex, Marital Status, and Tenure of Service on Job Stress, and Job Satisfaction of Health Workers in a Nigerian Federal Health Institution, International Multidisciplinary Journal, Ethiopia Vol. 8 (1), Serial No. 32, January, 2014:126-133 https://doi.org/10.4314/afrrev.v8i1.10 
Pitri, N., Suparman, L. and Nurmayanti, S. (2017). Pengaruh Stres Kerja, Kompensasi dan Pengembangan Karir Terhadap Komitmen Organisasional Perawat di Rumah Sakit Jiwa Mutiara Sukma Mataram Provinsi NTB. Jurnal Magister Manajemen Universitas Mataram, 4(3), 1-15.

Pradiptha, IDAGF., Widaningsih, and Anwar, S. (2018). The Development of Implementer Nurses' Career on Job Satisfaction and Turnover Intention. IMPACT: International Journal of Research in Applied, Natural, and Social Science, 6(9), 9-22, http://oaji.net/articles/2017/491-1538654000.pdf

Peraturan Menteri Kesehatan Republik Indonesia Nomor 40 Tahun 2017 Tentang Pengembangan Jenjang Karir Profesional Perawat Klinis.

Tobing, DSKL,(2009)., Pengaruh Komitmen Organisasional dan Kepuasan Kerja Terhadap Kinerja Karyawan PT. Perkebunan Nusantara III di Sumatera Utara, Jurnal Manajemen dan Kewirausahaan, Vol 11 (1), https://doi.org/10.9744/jmk.11.1.pp.\%2031-37

Siew PL., Chitpakdee and Chontawan R. (2011), Factors Predicting Organizational Commitment Among Nurses in State Hospitals, Malaysia., https://journals.iium.edu.my/kom/index.php/imjm/article/download/678/431

Sirajudin Noor, Nursalam and Tintin Sukartini (2020), Determinants of Organisational Commitment on Nurse's Performance, International Journal of Innovation, Creativity and Change. Volume 13, Issue 6, 2020, www.ijicc.net

Suhartini, (2009), Keadilan Dalam Pemberian Kompensasi, Jurnal Siasat Bisnis (JSB), Edisi Khusus JSB on Human Resources, https://journal.uii.ac.id/JSB/article/view/972

Wirani V., Arso SP and Suryawati C., (2017), Analisis Perbedaan Faktor Yang Berpengaruh Pada Kepuasan Kerja Perawat PNS dan Non PNS di RSUD Prof. DR. Margono Soekarjo Purwokerto (Studi di RSUD Prof. Dr. Margono Soekardjo Purwokerto), Jurnal Kesehatan Masyarakat, ,Volume 5, Nomor 4, Oktober 2017 (ISSN: 2356-3346) http://ejournal3.undip.ac.id/index.php/jkm 